\title{
Microarray Analysis of Cell Cycle and Apoptosis Biomarkers (P16, P21, P27, P53, Bcl-2, Bax, Bcl-xL And Cyclin D1) in Thyroid Papillary Carcinoma, Papillary Microcarcinoma and Lymph Node Metastasis of Thyroid Papillary Carcinoma
}

\section{Tiroid Papiller Karsinom, Papiller Mikrokarsinom ve Tiroid Papiller Karsinomun Lenf Nodu Metastazında Apoptoz ve Hücre Siklusu ile İlişkili Belirleyicilerin (p16, p2l, p27, p53, bcl-2, bax, bcl-xl ve siklin-D1) Doku Microarray Yöntemiyle Saptanması}

Gizem Akkaş Akgün ${ }^{1 *}$, Peyker Temiz ${ }^{2}$, Semin Ayhan ${ }^{2}$, Fazilet Uğur Duman ${ }^{3}$, Hasan Aydede ${ }^{4}$

${ }^{1}$ Kutahya Health Science University, Faculty of Medicine, Evliya Celebi Training and Research Hospital, Department of Pathology, Kutahya, Turkey.

${ }^{2}$ Manisa Celal Bayar University, Faculty of Medicine, Department of Pathology, Manisa, Turkey. ${ }^{3}$ Karsiyaka State Hospital, Laboratory of Pathology,Izmir, Turkey.

${ }^{4}$ Manisa Celal Bayar University, Faculty of Medicine, Department of Surgery, Manisa, Turkey

e-mail:dr.gizemakkas@gmail.com, peykerdemireli@gmail.com, seminayhan@gmail.com,faziugur@gmail.com, hasanaydede@hotmail.com ORCID: 0000-0001-9981-6648

ORCID: 0000-0001-6308-0157

ORCID: 0000-0002-8546-0705

ORCID: 0000-0001-9981-6648

ORCID: 0000-0002-1504-4140

*Sorumlu yazar/ Corresponding Author: Gizem Akkaş Akgün

Gönderim Tarihi / Received: 08.12.2020

Kabul Tarihi / Accepted: 23.05.2021 DOI: $10.34087 /$ cbusbed. 837637

Öz

Giriș ve Amaç: Bu çalışmanın amacı, tiroid papiller karsinom ve lenf nodu metastazının patogenezinde apoptoz ve hücre döngüsü ile ilişkili gen ürünlerinin rolünü belirlemektir.

Gereç ve Yöntemler: Tiroid papiller karsinom $(n=35)$, tiroid papiller mikrokarsinom (TPMK) $(n=22)$, TPK-lenf nodu metastazı (TPK-LNM) $(\mathrm{n}=12)$ ve adenomatöz nodülde $(\mathrm{AN})(\mathrm{n}=20)$ doku mikroarray yöntemi (TMA) kullanılarak p16, p21, p27, p53, bcl-2, bax, bcl-xL ve siklin D1'in immünohistokimyasal olarak boyanması incelendi. Bulgular: AN'lerin Bcl-2 boyaması, malign gruplarınkilerden önemli ölçüde farklıydı. p53, p16, p21 boyama yüzdeleri, malign gruplarda benign lezyonlara göre anlamlı olarak daha yüksekti. TPC-LNM grubu, primer tümör gruplarından daha yüksek p16 ve siklin D1 pozitifliğine sahipti. p27 boyanmasındaki en dikkat çekici fark, TPKLNM ve TPK grupları arasindaydı.

Sonuç: Hücre döngüsü düzenleyicilerinin, özellikle bcl-2 ailesinin, TPC karsinogenezinde önemli roller oynadığı sonucuna vardık. Siklin-CDK kompleksi (p16, p21, p27) üzerinde etkili olan sikline bağımlı kinaz inhibitörleri, malignite, progresyon ve kötü prognoz potansiyeli ile daha çok ilişkiliydi. p53, hem apoptozu hem de hücre döngüsünü düzenleyen proteinlerle etkileșime girerek TPC patogenezinde önemli bir rol oynar.

Anahtar kelimeler: Bcl-2, Bax, Bcl-xL, p16, p21, p27, p53, Siklin D1, Tiroid papiller karsinom.

\section{Abstract}

Objective: The aim of this study was to identify the role of apoptosis and cell cycle associated gene products in the pathogenesis of thyroid papillary carcinoma (TPC) and its lymph node metastasis. 
Materials and Methods: Cases of thyroid papillary carcinoma $(n=35)$, thyroid papillary microcarcinoma (TPMC) $(\mathrm{n}=22)$, TPC-lymph node metastasis (TPC-LNM) $(\mathrm{n}=12)$, and adenomatous nodule $(\mathrm{AN})(\mathrm{n}=20)$ were examined using tissue microarray method (TMA) by immunohistochemistry staining for p16, p21, p27, p53, bcl-2, bax, bcl-xL and cyclin D1.

Results: Bcl-2 staining of the ANs was significantly differed from those of malignant groups. p53, p16, p21 staining percentages were significantly higher in the malignant groups than in the benign lesions. TPC-LNM group had higher p16 and cyclin D1 positivity than the primary tumor groups. The most remarkable difference of p27 staining was between the TPC-LNM and TPC groups.

Conclusion: We concluded that cell cycle regulators, especially bcl-2 family, play important roles in TPC carcinogenesis. The cyclin-dependent kinase inhibitors acting on the cyclin-CDK complex (p16, p21, p27) were more associated with potential for malignancy, progression and poor prognosis. p53 plays an important role in the TPC pathogenesis by interacting with the proteins regulating both apoptosis and the cell cycle.

Keywords: Bcl-2, Bax, Bcl-xL, Cyclin D1, p16, p21, p27, p53, Thyroid papillary carcinoma.

\section{Introduction}

Thyroid neoplasms accounts for $1 \%$ of all cancers and are the most common type among the cancers of endocrine system. Thyroid papillary carcinoma (TPC) comprises about $80 \%$ of thyroid neoplasms. The frequency of TPC is gradually increasing worldwide [1,2].

Although there are a variety of studies on cell-cycle regulators including p16, p21, p27, p53, bcl-2, bax, bcl$\mathrm{xL}$, and cyclin D1 in thyroid lesions, to the best our knowledge, there exist no comprehensive study evaluating these regulators all together in the literature. The present study aimed to determine the roles of the $\mathrm{p} 16$, p21, p27, p53, bcl-2, bax, bcl-xL and cyclin D1 markers in the pathogenesis of TPC, thyroid papillary microcarcinoma TPMC and lymph node metastasis of thyroid papillary carcinoma (TPC-LNM) by investigating these interrelated gene products within a wide range of spectrum.

\section{Materials ve Methods \\ 2.1. Cases}

Thirty-four cases of TPC, 22 cases of TPMC and 12 cases of TPC-LNM that were diagnosed between the years 2006 and 2010 in the pathology department of university hospital were included in the study; 20 cases of adenomatous nodule (AN) were also included as controls. The same control groups was also used in our study in which determination-of apoptosis and cell cycle modulators (p16, p21, p27, p53, BCL-2, Bax, BCL-xL, and cyclin D1) in thyroid follicular lesions [3].

The diagnoses were confirmed by re-examining the hematoxylin-eosin (HE)-stained slides of the cases. The slide and the paraffin block containing the highest amount of the tissue representing the lesion were selected.

2.2. Preparation of Tissue Microarray Blocks and Sections

In order to obtain suitable blocks for tissue microarray method, routine paraffin and wax (Merck ${ }^{\circledR}$ product no:1115449020, Darmstadt, Germany) were mixed at a proportion of 1/10 (wax/paraffin) and melted at $64 \mathrm{oC}$. Blocks were obtained by pouring melted paraffin mixture onto the cassette on the 3DHISTECH Manuel TMA Kit (Budapest, HUNGARY) and then freezing at $0^{\circ} \mathrm{C}$ for 1 minute. Using TMA punch pencil, $2 \mathrm{~mm}$ of target tissues were taken from the blocks with marked lesion area.
Embedment procedure was performed in the way that each block would have contained 16-18 tissue samples. One slide was prepared from each block for HE staining and 10 slides were prepared for immunohistochemical staining.

\subsection{Immunohistochemical Staining Method}

Immunohistochemical staining was performed in 4micron sections taken from DMA blocks onto the positive-load specific slides via full-automatic device (Ventana Benchmark XT, Tucson, AZ, USA) and relevant immunohistochemical kit (DAB substrate system, AEC detection kit, EZ prep, LCS, SSC solutions, RBS, amplification, protease, block solutions, hematoxylin; Ventana, Tucson, AZ, USA).

For immunohistochemical staining, purified mouse antihuman p16 (INK4) Ab-4 (16P04) (LabVision/Neomarkers, Fremont, CA, USA, MS-887P1) (1/25 dilution- 40 minutes); mouse anti-human p21Waf1 monoclonal antibody (Clone SPM306) (Spring Bioscience, Pleasonton, CA, USA, E6330) (1/50 dilution- 1 hour; rabbit anti-human $\mathrm{p} 27 \mathrm{Kip} 1$ polyclonal antibody (Spring Bioscience, Pleasonton, CA, USA, E2600) (1/100 dilution- 12 minutes); rabbit anti-human p53 monoclonal antibody (Clone SP5) (Spring Bioscience, Pleasonton, CA, USA, M3050) (1/100 dilution- 48 minutes); rabbit anti-bcl 2 alpha polyclonal antibody (Spring Bioscience, Pleasonton, CA, USA, E17980) (1/200 dilution- 44 minutes); rabbit anti-bax monoclonal antibody (Clone SP47) (Spring Bioscience, Pleasonton, CA, USA,M3470) (1/50 dilution- 32 minutes); rabbit anti-human bcl-xL polyclonal antibody (Spring Bioscience, Pleasonton, CA, USA, E3370) (1/200 dilution- 16 minutes); rabbit anti-human cyclin D1 monoclonal antibody (Clone SP4) (Spring Bioscience, Pleasonton, CA, USA,M3040) (1/100 dilution- 32 minutes) were performed. Amplification was performed only in p21 and Bcl-2. Positive and negative controls were used in each of immunohistochemical staining.

The preparations with immunohistochemical staining were screened at 3DHISTECH Kft Company in Budapest, Hungary and digital images that would enable computed analysis were created.

2.4. Evaluation of Immunohistochemical Outcomes

All evaluations were performed via computer using Pannoramic Viewer 1.14 and DensitoQuant 1.14 
applications of 3DHISTECH TMA Module 1.14 program (Budapest, HUNGARY). Initially, orientation was provided for the tissues with images on the preparations with $\mathrm{HE}$ and immunohistochemical staining using 3DHISTECH Panoramic Viewer 1.14 application. Thereafter, Bcl-2, Bcl-xL and Bax cytoplasmic staining, as well as p53 nuclear and cytoplasmic staining, were analyzed using DensitoQuant 1.14 application. Three lesion areas with similar size and with the densest staining were marked on each image. The highest staining percentage in these three areas was considered. Evaluation of p16, p21, p27, and cyclin D1, which cause nuclear staining, was performed on digital images with $\mathrm{x} 100$ and $\mathrm{x} 400$ magnifications by two separate pathologists. Three consequent areas including 200 cells were counted and the highest staining percentage was taken as the basis.

\subsection{Statistical Analysis}

Data were analyzed using the Statistical Package for the Social Sciences (SPSS Inc., Chicago, IL, USA) version
15.0. Correlation was analyzed using Pearson's and Spearman's correlation analyses. Kruskal-Wallis test was used for comparison of more than two independent groups. The Mann-Whitney U test was used to compare differences between two independent groups when the dependent variable is either ordinal or continuous. Wilcoxon test was used when comparing two related samples, matched samples that came from the same population. A p value $<0.05$ was considered statistically significant.

\section{Results and Discussion \\ 3.1.Results \\ 3.1.1 Age and Gender}

The mean age, median age, gender ratio and percentage of the cases and largest group of age by decade and percentage of frequency are demonsrated in Table 1. There was no significant difference among the groups in terms of age $(p>0.05)$.

Table 1. The mean age, median age, gender ratio and percentage of the cases and largest group of age by decade and percentage of frequency

\begin{tabular}{|l|l|l|l|l|l|}
\hline & Mean Age & $\begin{array}{l}\text { Median } \\
\text { Age }\end{array}$ & $\begin{array}{l}\text { Female/ } \\
\text { Male } \\
\text { Ratio }\end{array}$ & $\begin{array}{l}\text { Female/Male } \\
\text { by percentage }\end{array}$ & $\begin{array}{l}\text { The largest age group by } \\
\text { decade (percentage) }\end{array}$ \\
\hline TPC (n=34) & $45.76 \pm 12.39$ & 45 & $29 / 5$ & $85.3 / 14.7$ & $60(32.3)$ \\
\hline TPMC (n=22) & $45.59 \pm 9.77$ & 47 & $17 / 5$ & $77.3 / 22.7$ & $50(36,5)$ \\
\hline TPC-LNM (n=12) & $48.41 \pm 12.22$ & 50 & $8 / 4$ & $66.7 / 33.3$ & $60(50)$ \\
\hline AN (n=20) & & & & & \\
\hline
\end{tabular}

TPC $=$ Thyroid papillary carcinoma, $\mathbf{T P M C}=$ Thyroid papillary microcarcinoma, $\mathbf{T P C} \_\mathbf{L N M}=$ Thyroid papillary carcinoma lymph node metastasis, $\mathbf{A N}=$ Adenomatous nodule

\subsection{Results of Immunohistochemical Staining}

It was detected that bcl-2, bax, bcl-xL caused cytoplasmic; p53 caused cytoplasmic and nuclear; p16, p21, p27 and cyclin D1 caused nuclear staining in the neoplastic and non-neoplastic thyrocytes (Figure 1-8). The mean staining percentage of 8 immunohistochemical markers among groups is demonstrated in Table 2.

Most cases of all groups were positive in bcl-2, bcl-xL but half of the lesions were stained with bax. p53 positivity was noted in $76.5 \%$ of the TPCs, in $91.2 \%$ of the TPMCs, and in $66.7 \%$ of the TPC-LNMs, however, no staining was observed in $60 \%$ of the ANs. Less than half of the lesions were stained with p16 in the AN group. p21 staining that was observed in the majority of TPC and TPC-LNM lesions was quite remarkable and much less observed in the AN group. In general, the p27 staining was low in all groups and no staining was observed in most cases. There were no samples p27 stained in the TPC-LNM group. The highest staining percentage of cyclin D1 was found in the TPC-LNM group, whereas the lowest percentage was found in the AN group.

Comparison of the bcl-2, p53, p16, p21 and cyclin D1 staining percentage of the AN group with those of the malignant groups revealed a significant difference $(\mathrm{p}<$ 0.05 for bcl-2, p53, p16 and $\mathrm{p}=0.000$ for $\mathrm{p} 21$ ). 
Table 2. The mean staining percentage of immunohistochemical markers among groups.

\begin{tabular}{|l|c|c|c|c|}
\hline $\begin{array}{c}\text { Immuno } \\
\text { histochemical } \\
\text { marker }\end{array}$ & $\begin{array}{c}\text { Thyroid papillary } \\
\text { carcinoma }\end{array}$ & $\begin{array}{c}\text { Thyroid papillary } \\
\text { microcarcinoma }\end{array}$ & $\begin{array}{c}\text { Lymph node } \\
\text { metastasis of thyroid } \\
\text { papillary carcinoma }\end{array}$ & $\begin{array}{c}\text { Adenomatous } \\
\text { nodule }\end{array}$ \\
\hline Bcl-2 & $88.28 \pm 13.83$ & $58.11 \pm 41.61$ & $59.32 \pm 24.71$ & $85.22 \pm 12.19$ \\
\hline Bax & $26.95 \pm 29.70$ & $8.66 \pm 15.21$ & $17.27 \pm 27.66$ & $3.88 \pm 7.26$ \\
\hline Bcl-xL & $78.89 \pm 23.49$ & $92.36 \pm 8.30$ & $87.89 \pm 7.32$ & $94.24 \pm 7.88$ \\
\hline p53 & $23.86 \pm 26.85$ & $8.39 \pm 12.27$ & $18.58 \pm 28.20$ & $1.38 \pm 2.00$ \\
\hline p16 & $3.23 \pm 3.44$ & $3.09 \pm 2.44$ & $12.08 \pm 9.87$ & $1.05 \pm 1.35$ \\
\hline p21 & $48.08 \pm 26.19$ & $47.95 \pm 32.75$ & $65.41 \pm 29.34$ & $9.75 \pm 10.81$ \\
\hline p27 & $1.47 \pm 1.61$ & $0.95 \pm 1.98$ & $0.00 \pm 0.00$ & $3.10 \pm 9.21$ \\
\hline Cyclin D1 & $34.08 \pm 27.35$ & $53.86 \pm 27.59$ & $72.50 \pm 16.58$ & $16.65 \pm 17.03$ \\
\hline
\end{tabular}

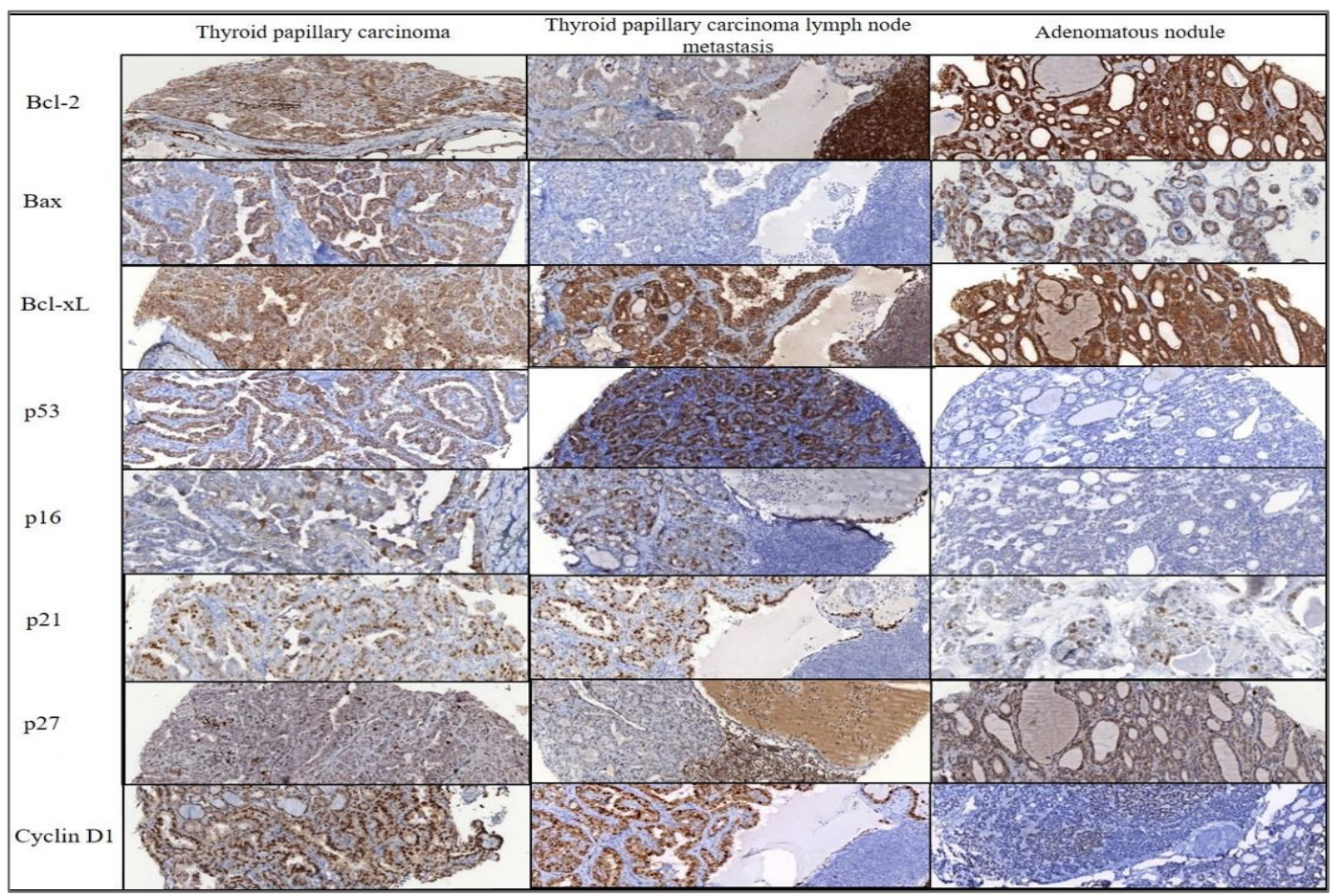

Figure 1. Nuclear staining of p16 (X100). 1A-Thyroid papillary carcinoma, 1B- Thyroid papillary carcinoma lymph node metastasis, 1CAdenomatous nodüle.

Figure 2. Nuclear staining of p21 (X100). 2A-Thyroid papillary carcinoma, 2B- Thyroid papillary carcinoma lymph node metastasis, 2CAdenomatous nodüle.

Figure 3. Nuclear staining of p27 (X100). 3A-Thyroid papillary carcinoma, 3B- Thyroid papillary carcinoma lymph node metastasis, 3CAdenomatous nodüle.

Figure 4. Nuclear and cytoplasmic staining of p53 (X100). 4A-Thyroid papillary carcinoma, 4B- Thyroid papillary carcinoma lymph node metastasis, 4C-Adenomatous nodüle.

Figure 5. Cytoplasmic staining of Bcl-2 (X100). 5A-Thyroid papillary carcinoma, 5B- Thyroid papillary carcinoma lymph node metastasis, 5CAdenomatous nodüle.

Figure 6. Cytoplasmic staining of Bax (X100). 6A-Thyroid papillary carcinoma, 6B- Thyroid papillary carcinoma lymph node metastasis, 6CAdenomatous nodüle.

Figure 7. Cytoplasmic staining of Bcl-xl (X100). 7A-Thyroid papillary carcinoma, 7B- Thyroid papillary carcinoma lymph node metastasis, 7CAdenomatous nodüle.

Figure 8. Nuclear staining of cyclin D1 (X100). 8A-Thyroid papillary carcinoma 8B- Thyroid papillary carcinoma lymph node metastasis, 8CAdenomatous nodüle. 
There was a significant difference between the TPC and TPMC in terms of the staining percentage for bcl-2, bax, bcl-xL ( $p<0.05$ for each).

The p16, p21, p27 and cyclin D1 staining percentages of the TPC-LNM (metastatic tumor) group were significantly different from the TPC and TPMC (primary tumor) groups ( $\mathrm{p}<0.05$ for each).

When immunohistochemistry staining was considered in a case-based manner, we found a high positive correlation between the staining percentages for $\mathrm{p} 53$ and bax $(r=0.73)$, a moderate positive correlation between the staining percentages for $\mathrm{p} 16$ and cyclin D1 $(r=0.36)$, a moderate positive correlation between the staining percentages for $\mathrm{p} 16$ and $\mathrm{p} 21(\mathrm{r}=0.30)$, and a high positive correlation between the staining percentages for p21 and cyclin D1 $(\mathrm{r}=0.64)$.

\subsection{Discussion}

Evaluation of the age and gender distributions of all groups revealed that the majority of the cases were women, in accordance with the conventional knowledge $[1,3]$.There were no cases below the age of twenty, and most of the cases were in their sixth decade of life. There was no significant difference among the groups in terms of age $(p>0.05)$.

In various studies, cytoplasmic bcl-2 staining intensifying in the perinuclear areas has been defined in benign lesions such as normal thyroid tissue, nodular goiter, and also in malign lesions such as thyroid follicular lesions and in well-differentiated thyroid carcinomas including TPC $[4,5]$. In accordance with the findings reported in the literature, we found that both malignant and benign samples exhibited cytoplasmic bcl2 staining in all groups and the highest rate of staining was observed in the TPC group [6] and the decrease in bcl-2 expression in the TPMC group was remarkable in the present study [7].However some studies have show bcl-2 was more expressed in benign tumor than in malignant tumors [8].

The significant differences between the AN group (which represents benign lesions) and the malignant groups in terms of bcl-2 staining percentage might be due the occurrence of a difference between the benign and malignant lesions in the apoptotic pathway in which the bcl-2 play an active role [4-7]. The lower staining rate in the TPMC group than in the AN group may be attributed to the effort of the organism to remove tumor cells by inducing apoptosis by means of decreasing the bcl-2 expression during the initial phase of the tumor. The bcl2 expression being higher in the TPC group than in all other groups indicated the prolonged lifetime of the cells of a tumor in this phase and the role of bcl-2 in carcinogenesis.
Lamba Saini et al. found intense cytoplasmic bcl-2 staining in normal thyroid tissue and detected more cell staining in PMC than metastatic PC. Therefore, they concluded that bcl-2 expression loss may be related to metastatic potential and poor prognosis [9]. In another study, they found that bcl-2 showed focal and weakly decreased expression in anaplastic thyroid carcinoma, supporting this finding [10]. Also in this study, bax showed a very intense and diffuse staining pattern [10]. Our findings were completely compatible with those of two investigations conducted in the same geographical region. In their study conducted in Greece, Letsas et al. [11] detected positive cytoplasmic staining for bax also in nodular goitres $(10 \%)$, being higher in the TPCs $(55 \%)$. The same study also emphasized a high bcl-2 staining in TPCs. In the study by Manetto et al. conducted in Italy, both bcl-2 and bax positivity, bcl-2 positivity being predominant, were determined in TPC [6]. The present study also revealed both bcl- 2 and bax staining in the TPC cases. Although this condition appears to be contradictory at first glance, Letsas et al. [11] attributed this to the fact that the bcl-2 and bax exhibit extensive amino acid homology and form homo- and heterodimers. Manetto et al. [12] suggested that it was more expressive to use the bcl-2/bax ratio rather than separate evaluations of the bcl-2 and bax staining and proposed that this ratio was in favor of bcl-2 in TPCs. In another study, expression of Bax in the PTC with LNM group was scored higher than NG $(\mathrm{p}<.01)$ and PTC without LNM $\quad(p<.05)$. So they suggested that immunohistochemical analysis of Bax could help diagnose PTC and in assessing the metastatic potential of lymph node in PTC [13].

In previous studies, bcl-xL positivity has been reported in TPCs [9,14]. Martinez-Brocca et al. [14] suggested that bcl-xL, an anti-apoptotic factor, was associated with poor prognosis and prognostic tumor variables such as regional LNM and distant metastasis and may be used as a strong predictor of tumor aggressiveness. In the present study, despite high bcl-xL staining observed in the tumor groups, no significant difference was found in the TPCLNM group, as previously advocated.

Based on the evaluation of the members of the bcl-2 gene family studied in the present study all together, it was concluded that cases of TPC exhibited diffuse positivity for bcl-2, bax, and bcl-xL members of the bcl-2 gene family and that the related findings were largely in accordance with the results of the previous studies. It was also concluded that this gene family, primarily the bcl-2, act in the pathogenesis of TPC.

p53 have been identified as a tumor suppressor gene which loss or mutation of p53 occurs in approximately $50 \%$ of all tumors [15] including thyroid cancer [16]. 
Two distinct staining patterns, nuclear staining and cytoplasmic staining intensifying around the nucleus, have been defined in TPC for p53 $[15,16]$. Similarly, in addition to nuclear staining, cytoplasmic p53 staining was observed predominantly in all case groups of the present study.

In the present study, the p53 staining pattern was in accordance with those reported previously [17-21], and the staining percentage was found to be significantly lower in the benign case group than in the malignant groups. Interpretation of this finding together with the results reported in the literature suggests that p53 is a malignity marker and plays a role in tumor pathogenesis. There are studies that find the relationship of p53 with lymph node metastasis [18], large tumor diameter [19] or capsule invasion [20] statistically significant, as well as in studies that do not find a significant relationship $[6,21,22]$. p53 is known to be the transcriptional activator of bax. Studies have demonstrated that thyroid cancers with high p53 staining rates also had high bax staining rates $[6,13]$. Similar to the findings in the literature, a high positive correlation $(\mathrm{r}=0.73)$ was found between the p53 and bax staining percentages in the present study.

Although p16 acts as an immunohistochemical marker exhibiting a nuclear staining pattern, paranuclear cytoplasmic staining may also be observed in thyroid lesions. Co-occurrence of the nuclear and cytoplasmic staining has been attributed to the overexpression of p16 protein and this localization change has been suggested to be responsible for the pathogenesis of TPC [23]. In the present case groups, both nuclear and cytoplasmic p16 staining, predominantly in the oncocytic cells of the lesions, was observed.

The finding that the staining percentage for p16 was significantly higher in the TPC and TPMC groups than in the AN group was in accordance with the findings reported previously and suggested the role of p16 in malignant transformation [23-26]. Expression of p16 protein has been found to be associated with extrathyroidal tumor extension and LNM in differentiated thyroid carcinomas [26]. In the present study, the fact that TPC-LNM group had significantly higher p16 positivity than primary tumor groups was considered significant in regard to the progression of the tumor.

In the present study, the malignant lesions were stained at a higher rate and more intensely for $\mathrm{p} 21$ as compared to the benign lesions. We considered that this finding might be helpful to diagnose a lesion, for which diagnosis is difficult, showing such a staining pattern as malignant. Previous studies have found that p21 have a high positivity rate in TPC-LNMs [27]. In our study, a high p21 positivity was also detected in the TPC-LNM group and it was concluded that p21 would influence the progression and poor prognosis.

Our findings regarding p27 support the opinion that the loss in the p27 expression indicates tumor aggressiveness, poor differentiation and metastasis capacity in thyroid cancers $[28,29]$. Do et al was found that decreased expression of p27 is associated with malignant transformation and extrathyroidal extension in papillary thyroid carcinoma [26].

It has been suggested that cyclin D1 overexpression was higher in aggressive tumors and regulator of the progression from $\mathrm{G} 1$ to $\mathrm{S}$ phase therefore it might be of importance in tumor progression and prognosis. Its overexpression has been reported in various carcinomas [30]. Cyclin D1 It has been reported that there was a significant difference between patients with and without metastasis in terms of percentage of nuclear staining for cyclin D1 and this might indicate metastatic potential in papillary microcarcinoma [11, 30-32]. Cyclin D1 was immunolabeled in more cells of metastatic PTC than of PMC was demostrated in Lamba Saini et al.study [11]. In the study conducted by Baric A. et al., cyclin D1 expression was observed in 6/8 (75\%) cases in TPMKs with lymph node metastasis, while staining in the group TPMKs without lymph node metastasis was 25/70 (37.5\%).(31). In the same study, P27 was shown to be stained at a rate of $3 / 8(37.5 \%)$ in TPMKwith lymph node metastasis and at a rate of $42 / 62(67.7 \%)$.in TPMK without lymph node metastasis [31]. In this study, it was found statistically significant that lymph node metastasis was associated with high cyclin D1 and low p27 in TPMCs [31]. Pesutic-Pisac et al. also found that cyclin D1 overexpression and decreased p27 expression indicated metastatic potential in TPC [29]. Our findings regarding cyclin D1 were in accordance with the suggestions reported in the literature.

When the staining features in the TPC-LNM group were evaluated all together, our findings supports the opinion that $\mathrm{p} 53, \mathrm{bcl}-2, \mathrm{p} 16$, and $\mathrm{p} 21$ are positive in TPC-LNM and that cyclin D1 positivity and p27 negativity predisposes to LNM. In a study conducted by Zafon et al. They did not see a significant difference between 19 TPK and 16 TPK-LNM groups between p21, p27, p16 and Bcl-2 staining rates [32].

\section{Conclusion}

In the present study, we concluded that cell cycle regulators, especially bcl-2 family, play important roles in TPC carcinogenesis. We also thought that the cyclindependent kinase inhibitors acting on the cyclin-CDK complex (p16, p21, p27) were more associated with potential for malignancy, progression and poor prognosis. The transcription factor p53 plays an 
important role in TPC pathogenesis by interacting with the proteins regulating both apoptosis and the cell cycle.

\section{References}

1. Lloyd, R.V, Osamura, R.Y, Klöppel, G, Rosai, J (editors), WHO classification of tumours of endocrine organs, 4 th edn. Lyon, France: IARC, 2017

2 .Thompson, L.D.R, Bishop, J, Malignant neoplams of the thyroid gland. Head and Neck Pathology, 3rd ed. Goldblum JR, series ed. Foundations in Diagnostic Pathology: Expert Consult. Philadelphia: Elsevier Saunders, 2018, 565-632.

3. Goldblum, J.R, Lamps, L.W, McKenney, J.K, Myers, J.L, editors. Rosai and Ackerman's surgical pathology. 11th edition. Elsevier; Philadelphia, PA: 2018.

4. Temiz, P, Akkaş, G, et al. Determination-of apoptosis and cell cycle modulators ( $\mathrm{p} 16, \mathrm{p} 21, \mathrm{p} 27, \mathrm{p} 53, \mathrm{BCL}-2, \mathrm{Bax}, \mathrm{BCL}-\mathrm{xL}$, and cyclin D1) in thyroid follicular carcinoma, follicular adenoma, and adenomatous nodules via a tissue microarray method. Turkish Journal of Medical Sciences, 2015; 45:865-71.

5. Gupta, A, Jain, S, et al. Expression of p63 and Bcl-2 in malignant thyroid tumors and their correlation with other diagnostic immunocytochemical markers, Journal of Clinical and Diagnostic Research, 2016, 10(7), EC04-8.

6. Cvejic, D, Selemetjev, S, et al. Apoptosis and proliferation related molecules (Bcl-2, Bax, p53, PCNA) in papillary microcarcinoma versus papillary carcinoma of the thyroid, Pathology, 2008, 40, 475480

7. Aksoy, M, Giles, Y, et al., Expression of bcl-2 in papillary thyroid cancers and its prognostic value. Acta Chirurgica Belgica, 2005, 105 , 644-648.

8. Al-Gharrrawi, S.A.R., Alkhafaji, A.H.M.A et al., Immunohistochemical expression of CD68, p53 and Bcl2 in thyroid tumors, Indian Journal of Forensic Medicine \& Toxicology, 2020 $14,1$.

9. Lamba Saini, M, Bouzin, C, et al., An appraisal of proliferation and apoptotic markers in papillary thyroid carcinoma: an automated analysis, PLoS One, 2016, 11 (2), e0148656.

10. Selemetjev, S.A, Savin, S.B et al., Changes in the expression pattern of apoptotic molecules (galectin-3, Bcl-2, Bax, survivin) during progression of thyroid malignancy and their clinical significance, The Wiener klinische Wochenschrift, 2015, 127(9-10), 337-44.

11. Letsas, K.P, Frangou-Lazaridis, M, et al. Transcription factormediated proliferation and apoptosis in benign and malignant thyroid lesions, Pathology International, 2005, 55, 694-702.

12. Manetto, V, Lorenzini, R et al., Bcl-2 and Bax expression in thyroid tumours, An immunohistochemical and western blot analysis, Virchows Archieve, 1997, 430, 125-130.

13. Lee, J.S, Jin, S.M et al., Expression of Bcl-2, Bax and p27 in Patients with Papillary Thyroid Cancer with or without Lymph Node Metastasis, Korean Journal of Otorhinolaryngology-Head and Neck Surgery, 2010, 53(3), 153-158.

14. Martínez-Brocca, M.A, Castilla, C, et al., Clinicopathological correlations of $\mathrm{Bcl}-\mathrm{xL}$ and Bax expression in differentiated thyroid carcinoma, Clinical Endocrinology-Oxford, 2008, 68, 190-197.

15. Cheok, C.F, Verma, C.S, et al., Translating p53 into the clinic, Nature Reviews Clinical Oncology, 2011, 8, 25-37.

16. Nikiforov, Y.E, Nikiforova, M.N, Molecular genetics and diagnosis of thyroid cancer, Nature Reviews Endocrinology, 2011, 7, 569-80.

17. Dwivedi, S.S, Khandeparkar, S.G et al., Study of immunohistochemical markers (ck-19, cd-56, ki-67, p53) in differentiating benign and malignant solitary thyroid nodules with special reference to papillary thyroid carcinomas, Journal of Clinical and Diagnostic Research, 2016, 10(12), EC14-EC19.

18. Balta, A.Z, Filiz, A.I, et al. Prognostic value of oncoprotein expressions in thyroid papillary carcinoma, Medical Oncology, 2012, $29,734-41$
19. Morita, N, Ikeda, Y, et al., Clinical significance of p53 protein expression in papillary thyroid carcinoma, World Journal of Surgery, 2008, 32, 2617-2622.

20. Horie, S, Maeta, H, et al., Overexpression of $\mathrm{p} 53$ protein and MDM2 in papillary carcinomas of the thyroid: Correlations with clinicopathologic features, Pathology International, 2001, 51, 11-5.

21. Hamzany, Y, Soudry, E, et al., Early death from papillary thyroid carcinoma, American Journal of Otolaryngology, 2012, 33, 104-8.

22. Shin, M.K, Kim, J.W, Clinicopathologic and diagnostic significance of p53 protein expression in papillary thyroid carcinoma, Asian Pacific Journal of Cancer Prevention, 2014, 15(5), 2341-4.

23. Lam, A.K, Lo, C.Y, et al., Clinicopathological roles of alterations of tumor suppressor gene p16 in papillary thyroid carcinoma, Annals of Surgical Oncology, 2007, 14, 1772-1779.

24. Boltze, C, Zack, S, et al., Hypermethylation of the CDKN2 / p16INK4A promotor in thyroid carcinogenesis, Pathology-Research and Practice, 2003, 199, 399-404.

25. Barroeta, J.E, Baloch, Z.W, et al., Diagnostic value of differential expression of CK19, Galectin-3, HBME-1, ERK, RET, and p16 in benign and malignant follicular-derived lesions of the thyroid: an immunohistochemical tissue microarray analysis, Endocrine Pathology, 2006, 17, 225-234.

26. Do, S.I, Kim, D.H, et al., Decreased expression of p27 is associated with malignant transformation and extrathyroidal extension in papillary thyroid carcinoma, Tumor Biology, 2016, 37, 3359-64.

27. Melck, A, Masoudi, $\mathrm{H}$, et al., Cell cycle regulators show diagnostic and prognostic utility for differentiated thyroid cancer, Annals of Surgical Oncology, 2007, 14, 3403-3411.

28. Okayasu, I, Osakabe, T, et al., P53 and p21(WAF1) expression in lymphocytic thyroiditis and thyroid tumors, Clinical Immunology and Immunopathology, 1998, 88, 183-191.

29. Pesutić-Pisac, V, Punda, A, et al., Cyclin D1 and p27 expression as prognostic factor in papillary carcinoma of thyroid: association with clinicopathological parameters, Croatian Medical Journal, 2008, 49, 643-649.

30. Lee, S.H, Lee, J.K, et al., Expression of cell-cycle regulators (cyclin D1, cyclin E, p27kip1, p57kip2) in papillary thyroid carcinoma, Otolaryngology Head and Neck Surgery, 2010, 142, 332-337.

31. Barić, A, Marković, V, et al., Cyclin D1, Ret and p27 expression in papillary thyroid microcarcinoma, Acta Clinica Croatica, 2017, 56 (1), 15-20.

32. Zafón, C, Castellví, J, et al., Usefulness of the immunohistochemical analysis of several molecular markers in the characterization of papillary thyroid carcinoma with initial lymph node metastasis, Endocrinología y Nutrición, 2010, 57, 165-9.

http://edergi.cbu.edu.tr/ojs/index.php/cbusbed isimli yazarın CBU-SBED başlıklı eseri bu Creative Commons Alıntı-Gayriticari4.0 Uluslararası Lisansı ile lisanslanmıştır. 